\title{
Empirical Analysis on the Multi-collaborative Teaching of Housing Architecture Course in Real Estate Economics Major During the Epidemic Period
}

\author{
Qin Guan ${ }^{1, *}$ \\ ${ }^{1}$ Guangzhou Xinhua University, Guangzhou, Guangdong 515200, China \\ *Corresponding author. Email: 5528635@qq.com
}

\begin{abstract}
Based on the teaching requirement of learning at home during the epidemic period, on the basis of fully excavating the existing resources, this paper analyzes the demand characteristics of House Architecture course for real estate economics speciality, and constructs multiple teaching methods, such as "online teaching platform + tools" collaboration, "self-built teaching resources and network teaching resources" collaboration, "traditional teaching materials and social software in favor by new generation" collaboration. The results of practical application are analyzed. It provides methods for the purpose oriented post epidemic era teaching of applied real estate economics undergraduate education.
\end{abstract}

Keywords: Multiple cooperation on line, Information teaching tools, Teaching reform.

\section{INTRODUCTION}

The spring semester of 2020 was the time when COVID-19 epidemic outbroke. Under the deployment of the Ministry of education, teachers in Colleges and universities actively respond the "Home Learning Plan". Relying on tools such as Tencent Conference, DingDing, Xuexitong and other modern intelligent tools, they integrate MOOC, Xuetang online and other excellent teaching resources. They actively carry out online teaching work, so as to complete the teaching task and ensure that students do not fall behind in learning due to the epidemic. But in the process of practice, we found the network teaching can not $100 \%$ realize the real "face-to-face" contact between teachers and students, it is easy to cause the failure of information feedback mechanism in the teaching and learning process of teachers and students. Therefore, we take the practice of multi collaborative teaching of Housing Architecture course in Real Estate Economics as an example to study how to efficiently complete the teaching task and improve the online teaching effect, so as to make a best practices example for the protection of major public events in the future.

\section{ANALYSIS OF THE CHARACTERISTICS OF HOUSING ARCHITECTURE COURSE FOR REAL ESTATE ECONOMICS MAJOR}

Housing architecture is a compulsory course for the major of Real Estate Economics. It is set up according to the requirement of real estate related economic activities. Therefore, this course is different from the course of housing architecture for engineering majors. Besides studying the composition of housing architecture, it also focuses on learning the principles of architectural drawing and architectural engineering budget. It is a course combining engineering knowledge with economics knowledge. In the process of online course design, we use SWOT model ("Figure 1") to analyze the related risks and opportunities as follows: 


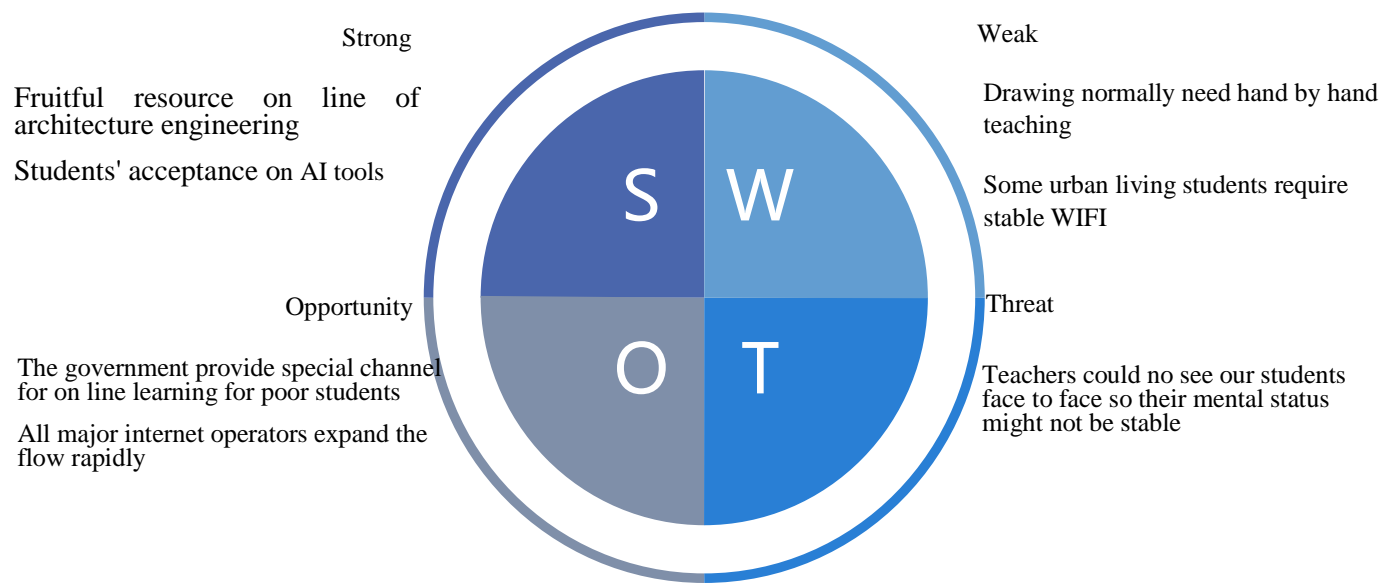

Figure 1 SWOT model of Housing Architecture on line.

\section{CONSTRUCTION OF MULTI COLLABORATIVE TEACHING MODE OF HOUSING ARCHITECTURE COURSE ON LINE}

Based on the analysis of the course characteristics, teaching requirement and existing resources, we design the framework and implementation roadmap of online teaching.

\subsection{Multiple Online Tools Chosen}

Two weeks before the semilar, we tested all existing tools we searched and negotiated with our students. We use Wechat + Tencent meeting and Xuexitong as major internet tools and APPs during the time of home study. They all can be used in mobile and computer so that students could choose the machine they have on hand and learn anywhere. And they have the individual advantage as below ("Figure 2"):

Wechat: It is the most popular Social Apps in China, which could easily transfer voice message, picture, document, video information instantly. We could also build group for students of this major. So urban living students could receive our notice in time and will not miss the class. We also use Wechat in drawing course as it could show the teacher's motion.

Tencent meeting: We tested all the existing meeting software and choose the most stable one. Tencent is the only one which has no downtime during morning, noon and the evening. Comparing with Ali Dingding, Tencent meeting has a more concise user interface, and less stutters at peak times. As our students are over 18, they have little interest on varieties such as "Pocket money", "lowers" in Dingding those popular in primary and middle school students, but a electric blankboard is more useful for them. Tencent meeting also has the advantage in recording the documents and videos. What's more, its user habit is simply as Zoom. As our students are mostly target to be professional businessman, we decide to use a software which they could easily adapt when they begin their career.

Xuetong: we choose Xuetong between rain class, cloud class and Xuetong. The main reason is that the network teaching of primary and secondary schools in China had already started at that time. According to the response of network users, we choose Xuexitong, which is mainly used by colleges and universities, to reduce the possibility of network downtime. In addition, Xuexitong also has the functions of checking in, publishing homework, correcting homework and arranging online examinations. Students can see the permanently saved courseware, videos and other learning materials here. 


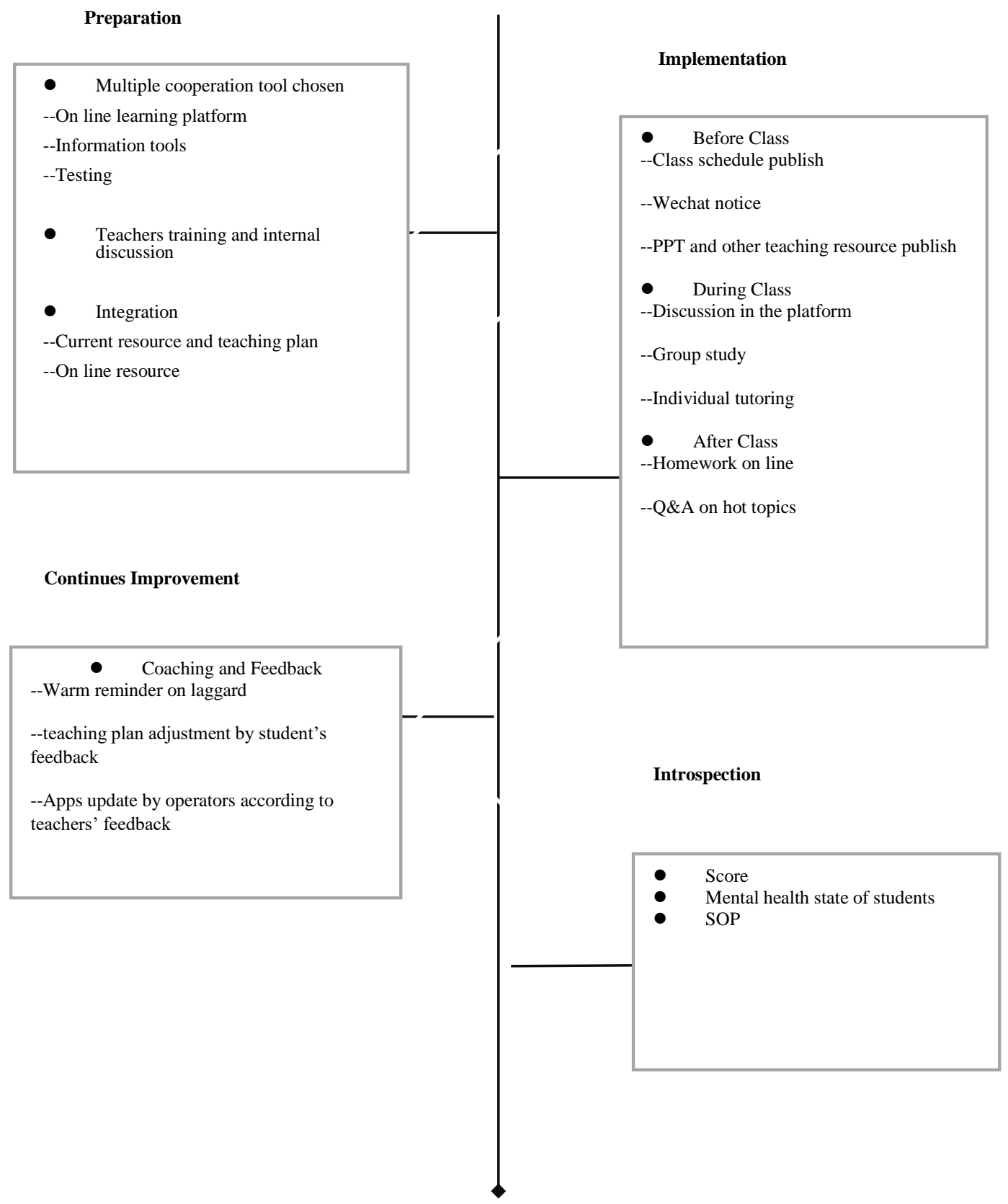

Figure 2 Roadmap of online teaching.

\subsection{Preparation and Adjustment of Lesson Plans and Teaching Materials, Testing and FEMA}

This semester coincides with the adjustment of the teaching plan of housing architecture course. We have increased part of the class hours of architectural drawing, reduced the learning difficulty of Chinese and foreign architectural history, and adjusted the corresponding class hours.
Therefore, it is necessary for teachers to live the ruler drawing on the Internet. For this reason, the teacher made a simple vertical bracket and bought live light and background cloth. Later, the Tencent conference launched the electronic set, and the teachers chose their own and online architectural photos as the background of each class, and tried to change the background of each class to match the content of this class. Because we couldn't lead the students to have on site visit during the epidemic period, we took advantage of the 600 year 
anniversary of the Forbidden City to collect some clips of the spring outing in the live broadcast room of the Forbidden City to analyze the shape, structure, decoration and cultural impression of ancient Chinese architecture. Strive to bring the essence of China culture to students in the shorter hours. For the courses that need on-site investigation such as building structure, the teacher collected the construction videos and pictures on the Internet to explain, making up for the students' regret that they could not go to the jobsite. Because the students do not have the conditions to install the charged CAD software at home, the teacher will show the specific operation through the prepared operation video shot and MOOC.
We use FEMA to predict the failure mode of elearning, and call all students to conduct two tests two weeks in advance. We specially selected the learning peak period of primary and secondary school students, tested all the teaching tools on the market, evaluated them from several important aspects, such as the number of downtime, the speed of file transmission, the friendliness of the interface, the applicability of the tools and network on the hands of students, and finally agreed to use the above three tools as the main learning tools of this course. For the situation that students or teachers are unable to attend classes due to network reasons, we have made FEMA prediction and confirmed that the remedial path is as follows ("Table 1"):

Table 1. FMEA of online teaching

\begin{tabular}{|c|c|c|c|c|}
\hline $\begin{array}{l}\text { Project and } \\
\text { function }\end{array}$ & Potential failure mode & Severity & Failure Cause & Recommended measures \\
\hline $\begin{array}{l}\text { Internet } \\
\text { operators } \\
\text { (WiFi, } \\
\text { broadband) }\end{array}$ & $\begin{array}{l}\text { Cut off the network, } \\
\text { downtime }\end{array}$ & Highest & $\begin{array}{l}\text { Multiple users are } \\
\text { blocked or } \\
\text { communication pipelines } \\
\text { are damaged }\end{array}$ & $\begin{array}{l}\text { Take BaiduYun as backup. } \\
\text { Students can download PPT } \\
\text { and ebook in advance, and } \\
\text { download the live video after the } \\
\text { network is restored }\end{array}$ \\
\hline $\begin{array}{l}\text { Software } \\
\text { service } \\
\text { providers } \\
\text { (Tencent } \\
\text { Meeting, } \\
\text { Xuexuetong, } \\
\text { Wechat) }\end{array}$ & $\begin{array}{l}\text { Cut off the network, } \\
\text { downtime }\end{array}$ & High & $\begin{array}{lr}\text { Multi user } & \begin{array}{r}\text { blocking, } \\
\text { paralysis, }\end{array} \\
\text { server } & \text { software } \\
\text { insufficient } & \text { soridicient uplink } \\
\text { server, insufficion } & \end{array}$ & $\begin{array}{l}\text { Teachers upload teaching } \\
\text { materials to Xuetong late at } \\
\text { night to avoid server paralysis. } \\
\text { Wechat group temporarily } \\
\text { replaced by QQ group, and } \\
\text { Tencent Meeting replaced by } \\
\text { Tencent Classroom. When the } \\
\text { network traffic jam is serious, } \\
\text { adjust the class time to idle time. }\end{array}$ \\
\hline $\begin{array}{l}\text { Students } \quad \text { (in } \\
\text { class) }\end{array}$ & $\begin{array}{l}\text { Don't listen carefully, } \\
\text { leave the screen to do } \\
\text { other things in class, or } \\
\text { open multiple interfaces } \\
\text { to play games }\end{array}$ & High & $\begin{array}{l}\text { Students stay at home } \\
\text { for a long time, and their } \\
\text { thoughts are slack. } \\
\text { Some students have to } \\
\text { help with housework, } \\
\text { take care of their } \\
\text { younger brothers and } \\
\text { sisters, cook, etc. }\end{array}$ & $\begin{array}{l}\text { Sign in, answer questions by } \\
\text { name and carry out group } \\
\text { discussion during the class to } \\
\text { draw attention. Ask all students } \\
\text { to turn on their microphones to } \\
\text { avoid playing games and } \\
\text { actually listening. Students who } \\
\text { do farm work are allowed to } \\
\text { have classes outdoors, while } \\
\text { students who do housework } \\
\text { have classes at the same time, } \\
\text { but make sure that students can } \\
\text { be seen on the screen. }\end{array}$ \\
\hline
\end{tabular}

In the class, teachers will conduct live class

\section{EMPIRICAL RESULTS AND TEACHING INTROSPECTION}

\subsection{Teaching Summary}

Before class, teacher released the classroom connection number, password and regular reminder through Tencent Meeting notice and Wechat group. Teachers will edit the courseware and electronic textbooks in the corresponding chapters of Xuetong in advance, so as to facilitate students' preview, in case that students can't see the image in the Tencent meeting due to network problems during the lecture process, which will affect the learning effect. through Tencent Meeting. Use EV software to record and save the video synchronously. In the process of teaching, all students can use computers, mobile phones or tablets to listen to teachers' live broadcast on Tencent Meeting platform. Teachers will also initiate network check-in from time to time to keep the classroom in order. Through questioning and interaction on the computer, we can understand the students' knowledge understanding and classroom performance.

At the end of the class, the teacher will publish the homework and the set answers on the learning link in Xuexitong. Students can finish their homework online and get the scores and explanations of the reference answers. The video of 
EV video will also be published in the corresponding chapters of Xuexitong. Students can review the teaching difficulties. Students can also express their opinions on relevant questions raised by teachers through Wechat group. The official account of the famous architectural design institute, famous universities and some famous architectural design public numbers was shared by Wechat on the group of the students. According to the attendance rate, classroom activity, discussion and homework quality, supervision and feedback, teachers can understand the students' interest and difficult points, timely adjust the teaching plan, supplement the blind spots and deficiencies in the teaching content, and adjust our teaching methods.

The assessment method has also been adjusted according to the situation of e-learning. In the past, our final performance evaluation was based on $40 \%$ of our usual performance and $60 \%$ of our exam performance. During the online learning period, our assessment standard is changed to $60 \%$ of the usual performance (middle test + usual homework + interaction) and $40 \%$ of the final exam. By increasing the proportion of the usual performance score, we can improve the students' concentration and participation in the learning stage. In the past, the goal orientation of short-term utility has changed to the process orientation of driving intrinsic potential and focusing on long-term interest. Our assessment of homework also breaks the habit of only using learning pass or question bank to do multiple-choice questions and other closed questions in the past. Instead, we focus on open homework oriented by discussion, analysis and self-searching for answers, such as reading analysis report, on-site visit or e-cloud visit experience, etc. This is also the change that we make in response to the social demand for the employment ability of economics majors. The goal of Real Estate Economics students to learn Housing Architecture is to correctly understand the architectural drawings, the architect's design ideas, the structure and cost of the house, and the investment value of the building. These needs cannot be achieved by doing closed questions alone.

\subsection{A Survey of Students' Learning Effect}

At the end of the semester, we used Questionnaire Star to survey all the students who participated in the study. We used a general template in it and modified some questions. The main problems are as follows (see "Table 2"):
--Q1. How about the interaction between you and teachers in the process of e-learning during the epidemic period:

The interaction effect is very good, effectively promote learning takes $31.03 \%$. The interaction effect was good, which was helpful to learning takes $48.28 \%$. That means $79 \%$ of the students have positive feedback on interaction.

--Q2. Please comment on your preview and homework.

Completed on time, with good quality takes $51.72 \%$, completed on time, and the quality is generally takes $44.83 \%$. So $96 \%$ of the students believe on line homework have limited affect V.S. tradition ways.

--Q3. To highlight the key points, solve the difficult points, teach skillfully and clearly

Dissatisfied rate is $0 \%$. The teacher is shocked in this result as everyone is satisfied. It might due to the teachers' extra effort in the whole teaching process.

--Q4. The teacher gave out necessary help, guidance and feedback for online learning of this course, and the online teaching was smooth and orderly.

Dissatisfied rate is $0 \%$. The teacher is also shocked as on Q3. Now we can clearly see that teachers exert herself during this period.

--Q5.During the epidemic period, I can make full use of network teaching resources to learn this course

$100 \%$ students agree or strongly agree on this question.

--Q6. During the epidemic period, I can actively participate in online learning

$100 \%$ students agree or strongly agree on this question. It seems they have not give up themselves at home to be a couch potato.

--Q7. Which of the following is the most important in e-learning.

Analysis of key and difficult points takes $62.07 \%$, Video quality takes $27.59 \%$, Online interaction takes $10.34 \%$. No one choose Evaluation of learning effect. This shows that students and teachers are not the same focus. Teachers pay attention to students' overall curriculum absorption, and students pay attention to those difficult problems. 
Q8. Which of the teaching methods used by teachers during the epidemic period are you satisfied with

Live interactive teaching + online discussion and Q \& A takes $62.07 \%$, Online platform courses takes $17.24 \%$, Interactive teaching of network platform courses + course teaching group takes $13.79 \%$, Teaching resources release before class + students' self-study plus assignment and feedback takes 6.9\%. 0 students choose QQ group Wechat group nail group push course learning materials. The main reason why the live interactive teaching is so popular is that the students can see the teachers' and students' faces and feel the collective warmth during the epidemic. Reduce loneliness at home.

Table 2. The most satisfied communication tool for online teaching

\begin{tabular}{|c|c|c|c|}
\hline Subject & Total & Percentage & \\
\hline Ali Dingding & 1 & 4 & $3.45 \%$ \\
\hline Wechat group & 22 & & $75.86 \%$ \\
\hline $\mathrm{QQ}$ group & 5 & & $17.24 \%$ \\
\hline Xuexitong & 13 & & $44.83 \%$ \\
\hline Tencent meeting & 15 & & $51.72 \%$ \\
\hline China mooc & 4 & & $13.79 \%$ \\
\hline Others & 1 & 4 & $3.45 \%$ \\
\hline
\end{tabular}

What are you most satisfied with as a communication tool for online teaching? (see "Table 2")

We have tested all above tools with all the students twice before the semester begin, after the ending, it shows that the tools we choose are correct. As the students have other course study on line by other teacher with other tools, our choice are still on top 3 .

Table 3. Effective ways of interaction in e-learning

\begin{tabular}{|c|c|c|c|}
\hline Subject & Total & Percentage & \\
\hline Live video / voice interaction & 21 & & $72.41 \%$ \\
\hline Barrage, email, forum & 9 & & $31.03 \%$ \\
\hline Attendance checking, voting & 17 & & $58.62 \%$ \\
\hline Online group Seminar & 5 & & $17.24 \%$ \\
\hline
\end{tabular}

C3. What do you think are the more effective ways of interaction in e-learning? (see "Table 3")
Our students are not popular on barrage and forum, which primary and secondary school 
students crazily hooked on them. The teacher also

class.

found this and changed the interaction ways in the

Table 4. Online activities can promote online teaching

\begin{tabular}{|c|c|c|c|}
\hline Subject & tal To & Percentage & \\
\hline $\begin{array}{l}\text { Teachers' real-time video and audio } \\
\text { interaction, question answering online } \\
\text { group discussion and cooperation }\end{array}$ & 22 & & $75.86 \%$ \\
\hline $\begin{array}{l}\text { Increase the content and class } \\
\text { hours of special education }\end{array}$ & 10 & & $34.48 \%$ \\
\hline Online in class examination or test & 13 & & $44.83 \%$ \\
\hline $\begin{array}{ll}\text { Intelligent } & \text { recommendation } \\
\text { learning resources } & \end{array}$ & 11 & & $37.93 \%$ \\
\hline $\begin{array}{l}\text { Learning status intelligent } \\
\text { monitoring and feedback, remind }\end{array}$ & 5 & & $17.24 \%$ \\
\hline
\end{tabular}

C4. Which online activities do you think can promote online teaching (see "Table 4")

As traditional Chinese students, they are still have less confidence on self-learning. They still require the usual quiz to familiarize themselves with the course, fearing that the final exam will be affected.

Table 5. Your e-learning situation

\begin{tabular}{|c|c|c|c|}
\hline Subject & Total & Percentage & \\
\hline Consciously choose the network resources to learn & 15 & & $51.72 \%$ \\
\hline $\begin{array}{l}\text { Conscientiously complete the online teaching and } \\
\text { learning task }\end{array}$ & 19 & & $65.52 \%$ \\
\hline Actively communicate with teachers and students & 7 & & $24.14 \%$ \\
\hline Will take the initiative to arrange daily study & 9 & & $31.03 \%$ \\
\hline They are very satisfied with their own learning situation & 5 & & $17.24 \%$ \\
\hline Not interested in learning & 0 & & $0 \%$ \\
\hline
\end{tabular}

C5. Your e-learning situation during the elearning period (see "Table 5")
The results show that our students are more keen on self-study than chat with classmates after class. They still keep shy on the net. 
Table 6. The most satisfied measure to improve everyone's enthusiasm and learning effect

\begin{tabular}{|l|l|l|}
\hline Subject & Iota & Percentage \\
\hline $\begin{array}{l}\text { Many times before class notice requirements and } \\
\text { learning guidance }\end{array}$ & 18 & \\
\hline $\begin{array}{l}\text { Teachers use a variety of teaching methods to try to } \\
\text { ensure that each student does not fall behind }\end{array}$ & 19 & \\
\hline $\begin{array}{l}\text { The teacher has prepared the rich study resources for } \\
\text { us, let us develop the train of thought }\end{array}$ & 19 & \\
\hline $\begin{array}{l}\text { When we encounter problems, teachers patiently and } \\
\text { timely give answers and help. }\end{array}$ & 15 & \\
\hline $\begin{array}{l}\text { The teacher gave special care and guidance to the } \\
\text { students who could not attend and Study on time due } \\
\text { to special circumstances in the class. }\end{array}$ & 12 & $65.52 \%$ \\
\hline
\end{tabular}

C6. Your e-learning situation during the epidemic period (see "Table 6")

Table 7. For teachers to improve in the process of online learning

\begin{tabular}{|l|l|l|}
\hline Subject & Total & Percentage \\
\hline Solve my problems in time & 19 & \\
\hline Timely feedback of course assignments & 22 & \\
\hline Supervise us & 10 & \\
\hline $\begin{array}{l}\text { Participate in our discussions and guide us to think } \\
\text { positively. }\end{array}$ & 14 & \\
\hline
\end{tabular}

C7. What do you need teachers to do in the process of online learning (see "Table 7")

On this question, we found the shortage of elearning. During the epidemic period, teachers spend twice as much time preparing lessons as

Table 8. Aspects your teachers have done better

\begin{tabular}{|l|l|l|l|}
\hline Subject & Pota & Percentage \\
\hline $\begin{array}{l}\text { The teaching resources pushed before class are very } \\
\text { suitable for online learning }\end{array}$ & 24 \\
\hline Be able to explain the key and difficult points clearly & 15 & \\
\hline $\begin{array}{l}\text { The learning tasks are assigned appropriately and the } \\
\text { assignments are arranged reasonably }\end{array}$ & 18 & \\
\hline $\begin{array}{l}\text { The proper teaching method is very suitable for the current } \\
\text { network learning }\end{array}$ & 13 & $\%$ \\
\hline $\begin{array}{l}\text { The online classroom is rich in content and can stimulate } \\
\text { learning enthusiasm. }\end{array}$ & 6 & $\%$ \\
\hline
\end{tabular}

C8. Which of the following aspects do you think your teachers have done better (see "Table 8") normal classes, so they have less time to answer questions. In addition, students still have no confidence in changing the way of assessment, grasp the open questions and pursue the only answer. 
have too many tools use during the class, the switching of screen will brings downtime on their screen. Some micro course and webside video has no image of voice occasionally. These problems will cause them to be unable to keep up with the pace of class.

Table 9. The advantages of online teaching

\begin{tabular}{|c|c|c|}
\hline Subject & Total & Percentage \\
\hline Cultivating the ability of self-learning & 17 & $58.62 \%$ \\
\hline Free to control learning time & 17 & $58.62 \%$ \\
\hline Improve the students' self-control ability & 14 & $48.28 \%$ \\
\hline It can learn anytime and anywhere & 15 & $51.72 \%$ \\
\hline Richer learning resources & 14 & $48.28 \%$ \\
\hline $\begin{array}{l}\text { The content of online courses can be looked } \\
\text { back, which is easy to understand and } \\
\text { consolidate }\end{array}$ & 16 & $55.17 \%$ \\
\hline $\begin{array}{l}\text { Make famous teachers and famous courses } \\
\text { fully share }\end{array}$ & 3 & $10.34 \%$ \\
\hline Diversified forms of online teaching & 5 & $17.24 \%$ \\
\hline
\end{tabular}

C9.The advantages of online teaching (see "Table 9")

From the above questions and answers, students are satisfied with online learning tools, courseware and teaching skills. But they reflect some problems in the process of online learning. For example, a large number of users are online at the same time, causing network congestion, and some software systems such as Xuexuetong and MOOC are down. Some famous teachers and famous courses are free for only a short period of time and they have no time to complete their interest topic.

\subsection{Teaching Reflection}

After a semester of practice, we summarize the teaching methods, effects and students' feedback. Due to the change of assessment methods, we do not measure the success of online teaching by performance, but take the improvement of students' ability as the direction. Overall, the effect is better than expected. But there are also some problems that cannot be solved by network teaching, including the following points:

Students' psychological problems: Due to the reduction of outing, studying at home for a long time and the increase of friction between some students and family members, they might study and live with negative emotions and affect their interest in learning. In addition, some students with good family conditions indulge in the comfortable environment at home and unconsciously put their energy on entertainment such as reading novels and playing games. They need teachers to remind them of preview, homework and other things about study. Some students with weak discipline need the Study Committee to remind homework. Students with siblings basically have to bear a certain amount of housework at home, so they have to learn to use fragmented time to study.

Communication between teachers and students: compared with face-to-face communication, network communication is less real-time and restricted by communication conditions. In addition, students live in a dormitory at school, which is convenient for students to learn from each other when they review after class. When they study at home, students will feel isolated when they encounter problems. In the past, teachers would reserve a certain face-to-face question answering time in school every week, which is not easy to realize during online learning.

Workload of teachers: the workload of teachers during home study is nearly twice that of normal semester. Not only all live courses should be recorded again, but also all courseware ppt and 
videos should be produced and uploaded to Xuexitong and Baiduyun. Because the students all over the country take online classes during this period of time, the upload work should be carried out in the late hours when the network speed is fast. In order to improve students' interest, all cases are re prepared for the past two years'. Teachers need to push relevant articles and papers in Wechat group and discuss after class, so as to continuously activate students' interest in learning and avoid the aesthetic fatigue of learning at home.

On the other hand, through online learning, students' self-management ability and self-learning ability, independent analysis and problem-solving ability, as well as the ability to write research reports have been improved to a certain extent. Especially for students who eager to learn, learning at home can be more focused, and students can take advantage of a large number of free network resources to learn many related university courses. Through network teaching, teachers also cultivate good software application ability and broaden their research direction.

\section{CONCLUSION}

Education always takes on the responsibility of moral character. Therefore, whether learning at home or learning in school, we still pay attention to combine the relevant real estate economics knowledge in the class to cultivate students' patriotic feelings. Guide students to transform knowledge into application ability and serve the society. With the development of normal teaching in the new semester, online learning has completed its historical mission, and our efforts also ensure the teaching effect of learning at home. For both teachers and students, this process of common progress can provide reference for future teaching and learning.

\section{AUTHORS’ CONTRIBUTIONS} Guan.

This paper is independently completed by Qin

\section{REFERENCES}

[1] Ministry of Education. Notice of the Ministry of education on delaying the start of spring semester in 2020 [EB/OL]. http://www.moe.gov.cn/jyb_ xwfb/gzdt_gzdt/s5987/202001/t20200127_41 6672.html, 2020-01-29.
[2] Zhang Ping, Liu Yuehua, Tang Lingbing, Shi Changfa. Experience summary of emergency online teaching during the epidemic period of COVID-19[J]. Wireless Internet Technology, 2020(2): 165-166.

[3] Li Meiru, Li Qiuling, Hou Zhimin, Qi Ying, Fan Shuanghu. Practice and Thinking of Online Live Teaching During the COVID-19 Epidemic [J]. Journal of Langfang Normal University (Natural Science Edition), 2020 (4): 116-118

[4] Dan Wu, Min Qian, Yun Ding, Yanyan Wang, Fengchuan $\mathrm{Xu}$, Exploration and practice of integrating network tools into course teaching under epidemic situation - Taking optics course as an example [J]. Journal of Higher Education, 2020(7): 1-6

[5] Zhang Biao, Liu Ze, YU Biao. Research on Improving the Teaching Quality of Colleges and Universities During the Epidemic $[\mathrm{J}]$. Education Teaching Forum2020(51):347-348

[6] Hao Guan. Analysis on the advantages and disadvantages of network teaching under the background of epidemic prevention and control - Based on the big data analysis of an engineering university in Jiangsu Province [J]. The Science Education Article Collects, 2020(35):36-39 